\title{
Synthesis Study on Argumentation in Science Education
}

\author{
Yurdagül Boğar ${ }^{1}$ \\ ${ }^{1}$ Faculty of Education, Hakkari University, Hakkari, Turkey \\ Correspondence: Yurdagül Boğar, Faculty of Education, Hakkari University, Hakkari, Turkey.
}

Received: January 14, 2019

doi:10.5539/ies.v12n9p1

\begin{abstract}
In current educational research, there is an increasing acceptance among researchers to emphasize that students must be educated on scientific ways of thinking. Simultaneously, science education practice has focused on the development of scientific thinking skills which are associated with scientific inquiry rather than memorization skills. When it comes to scientific practices, educational reforms highly emphasize scientific practices such as argumentation in science education. Therefore, the purpose of this study is to conduct a synthesis study on argumentation in science education. In order to achieve this purpose, this topic will be reviewed under seven main headings within the current study. These are development of argumentation theory, argumentation approaches, argumentation models used in science education, student's role in argumentation, teacher's role in argumentation, activities that create an argumentation environment, difficulties associated with the implementation of the argumentation in the learning environment and scientific argumentation respectively. In addition, some sub-headings will follow the main headings.
\end{abstract}

Keywords: argumentation, literature review, science education

\section{Development of Argumentation Theory}

According to Bricker and Bell (2008), argument is a core practice for scientific discourse. Scientific data are vetted and eventually accepted as a theory. As a theory, argumentation went through a progressive process starting from the time of Aristotle to the $21^{\text {st }}$ century. However, in Aristotle's argumentation theory, some factors were not taken into consideration. The next was Toulmin's (1958) argumentation pattern. It was developed to investigate argumentations of individuals and to consider contextual factors in argumentation rather than the formal argumentation structure (Sampson \& Clark, 2008). However, Toulmin's argumentation pattern did bring about some methodological challenges (Driver, Newton, \& Osborne, 2000). Consequently, other argumentation frameworks were developed such as Johnson and Blair's (1994) non-formal argumentation and Walton's (1996) presumptive reasoning. In these frameworks, it was emphasized that the relationship between the premises of arguments and conclusions were important in the evaluation of argument quality (Greenwell, Knight, Holloway, \& Pease, 2005). In summary, these argumentation frameworks established the foundations of the argumentation theory.

\subsection{Definitions of Argumentation}

In the educational context, Sampson and Clark (2008) argued that the term argument identifies an element used in constructing a claim, whereas argumentation identifies the process and discourse. There are different definitions about argumentation that are made by lots of scientists. Giving the definitions made about argumentation in the field literature chronologically would be significant in the sense that it would enable us to see the different definitions and changes that happened to the concept over time. Toulmin's (1990) argumentation was defined as the process of using data, justifications, contributions and disproving in order to convince people about the validity of a certain claim. In another definition on argumentation argued by Kuhn (1993), she stated that argumentation is fundamental to science activity because science education researchers construct arguments, evaluate evidence, form warrants to endorse their hypotheses, and discuss alternative explanations. Mason and Santi's (1994) argumentation was defined as a way of communication that is 'epistemic' which deals with the social composition of knowledge, 'analytic' which deals with structure, consistency and getting to a conclusion, and 'critical' which deals with current situations and possibilities of the conditions. According to Driver and his colleagues (2000), argumentation is a reasonable process. Reason is an academic discipline that exposes significant rules in order to reach results from related foundations. In this sense, argumentation can be thought of as a social activity within a 
special group in a social environment and as an individual activity through writing, thinking and speaking. According to Nussbaum and Bendixen's (2003) definition, argumentation is creating justifications that aim to solve a problem or answer a question and criticize.

In general, when we look at the definitions about the concept of argumentation above, we see different ideas about whether this process has been created by a community or by the processes in the mind of an individual. In literature, it is known that as a common opinion, argumentation process is both an individual and social activity. The individual creates specific arguments, designs and evaluates them in her/his mind. In social processes, two or more individuals create different arguments on a specific topic, and they argue about the validity of these arguments for evaluation.

When we look at all the definitions in the literature, we see that argumentation is an approach that came to existence to define the logical problems in daily life. However, argumentation and reason are terms that should not be mixed with each other because argumentation and logic (reason) are two different disciplines. Each has a different field of work and each serve a different purpose when practiced in the classroom. In classroom practices, argumentation works on the activity of arguing and aims to teach 'how to argue better' to students. Logic (reason), however, works on the process of reasoning and aims to teach the students 'how to make a better reasoning' (Binkley, 1995; Driver et al., 2000).

\section{Argumentation Approaches}

Van Eemeren et al. (1996) divided argumentation into three different groups - analytic, dialectic and rhetoric and then defined them as:

Analytic argumentation is based on the theory of logic and may include hints (periphrases), material practices, comparisons and incorrect thoughts. In such arguments, a conclusion is reached by induction or deduction.

Dialectic discussions include finding a reason which is not accepted as truth and are part of daily life. The idea of reaching new ideas through argument and reasoning about our present ideas lies in the basis of such discussions.

Rhetoric discussions are used for explaining the strength of a claimed idea to others and convincing them. Therefore, making someone accept an idea or showing an effort to convince others is at the heart of these discussions. Because of its effect on convincing opponents, foundation is the most important part of rhetoric discussions, and in argumentation, presenting proof is superiority (Driver et al., 2000; Jiménez-Aleixandre et al., 2000; Van Eemeren, Grootendorst, Henkemas, Blair, Johnson, Krabbe, \& Zarefsky, 1996).

Aristo's three argumentation types (analytic, dialectic and rhetoric discussions) are given below and their characteristics are compared (Van Eemeren et al., 1996):

Table 1. Characteristics of analytic, dialectic and rhetoric argumentations

\begin{tabular}{llll}
\hline Argumentation & Analytic & Dialectic & Rhetoric \\
\hline Purpose & Accurate & Acceptable & Convincing \\
Foundation & Correct as obvious & Acceptable & Convincing the audience \\
Result & Reasonable & Reasonable & Convincing the audience \\
Theory & Reasonable & Dialectic & Rhetoric \\
\hline
\end{tabular}

\section{Argumentation Models Used in Science Education}

Toulmin model is the most common and first used argumentation model in science education (e.g., Driver et al., 2000; Erduran, Simon, \& Osborne, 2004; Erduran \& Jiménez-Aleixandre, 2007; Kutluca, 2012; Özkara, 2011; Simon, Erduran, \& Osborne, 2006). Later, some models of science education were introduced due to some disadvantages of this model (e.g., Kelly \& Takao, 2002; Lawson, 2003; Sampson \& Clark, 2008; Schwarz, Neuman, Gil, \& İlya, 2003). Sampson and Clark (2008) collected these models under two headings: Domain-General and Domain-Specific.

\subsection{Domain-General (Independent) Models}

Models created under this title allow not only a single field but also the evaluation of the generated arguments in other fields. Domain-general models are explained in Table 2. 
Table 2. Domain-general models

\begin{tabular}{ll}
\hline & $\begin{array}{l}\text { Argumentation as a reasoning process in the Toulmin (1958) model is defined as the main component of data, claim, } \\
\text { woulmin }\end{array}$ \\
Argumentation & (1990) model, qualifiers and rebuttal components have been added to the basic components of data, claim, warrant \\
and backings, and to analyze more complex and advanced arguments (Aktamış \& Hiğde, 2015; Sampson \& Clark, \\
2008).
\end{tabular}

\subsubsection{Toulmin's Argumentation Model}

In his model, Toulmin defined argumentation as a pattern which has related components as Data, Claim, Warrant and Backings, and for more complex arguments as Qualifiers and Rebuttals (Toulmin, 1958). Moreover, in his book entitled the Uses of Argument, he analyzed many arguments to explain everyday argumentation and presented a model, which included the elements of an argumentation and showed the relationships between them (Figure 1).

The main components of this model are:

- Data: These are the facts, the evidences, or observations that support the claim.

- $\quad$ Claim: The conclusion drawn from the merits to be built.

- Warrants: These are the causes such as principles that show the connection between the data and claim.

- Backings: These are defined as generalizations that support particular warrants.

Driver, Newton, and Osborne (2000) formulated these main components of an argument in a sentence like: "because (data)... since (warrant).... on account of (backing)... therefore (claim)" (p. 293).

In addition to the main components above, Toulmin (1958) identified two more components included in complex arguments:

- Qualifiers: The limitations on the claim when the claim is accepted as true.

- $\quad$ Rebuttals: These are the conditions when the claim is not accepted as true. They may be in contradiction with any other basic component of the argument.

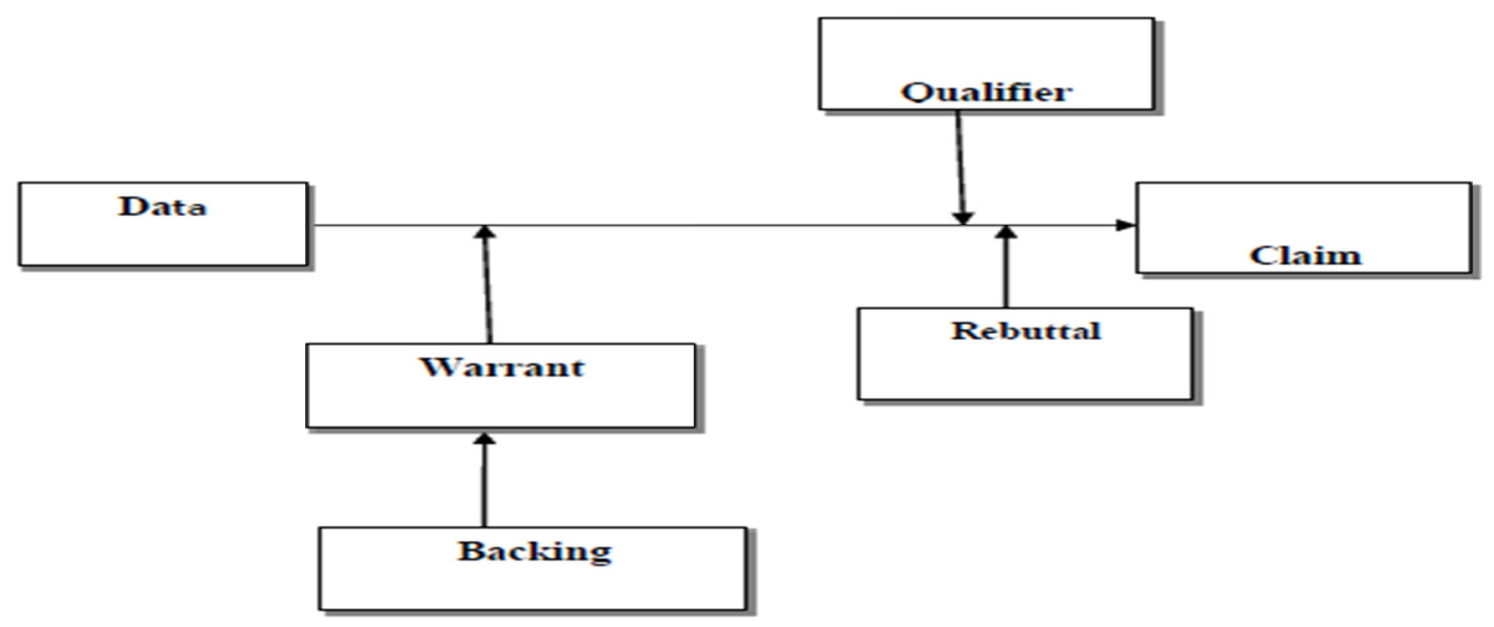

Figure 1. Toulmin's Argument Pattern. Adapted from Argumentation in Science Education: Perspectives from classroom-based research (p. 57, by Erduran, 2008, Dordrecht, London: Springer) 
Toulmin's argumentation model has a major contribution to the literature on the explanation of the argument concept (Erduran et al., 2004; Osborne, Erduran, \& Simon, 2004a). According to Aldağ (2005), instead of just witnessing the process, students get involved and become a part of that process, thanks to Toulmin's argumentation model. This method also improves the students' ability to ask questions and makes them learn when it would be proper to ask a specific question. Thanks to this model, students learn to be able to change their claims, to be open to criticism and to revise their claims according to criticisms. It gives the opportunity to understand that sometimes people cannot agree on human relationships and that they can solve these disputes by making discussions. Additionally, Toulmin's argumentation model slows down the course-teaching process and makes it easier for students to understand (Leeman, 1987).

In Toulmin's argumentation, claim is the ground for all arguments. For a good argument, the claim must be justified by providing a warrant and a backing. However, Driver, Newton, and Osborne (2000) argue that Toulmin's argumentation has mainly three limitations. These limitations are stated below:

1) It only gives idea about the structure of the arguments but does not evaluate their correctness.

2) It does not consider the dialogic structure of the argumentation, that is, recognition is given to interactional ways of the argumentation.

3) Toulmin's scheme is decontextualized, that is linguistics and situational contexts are not emphasized (Driver, Newton, \& Osborne, 2000, p. 294).

In order to construct argumentation, it is required to present the validity of claims, evaluate the alternatives and proofs and with all these, texts are supposed to be interpreted. However, since the method of argumentation in schools is not entirely in classroom culture, problems can arise in the formation of general strategies that will allow students to participate in the argumentation process. Osborne, Erduran, and Simon (2004b) have pointed out that the Toulmin argument model poses difficulties in the implementation of class-based verbal data, although the argument is used as a structure for identification. They have emphasized that the main difficulty is what the claim, data, justification and supporting are to be considered as. Erduran (2008) stated that one other major difficulty about the Toulmin model was the coding of arguments. The researcher emphasized that the questions "If the components of an argument repeat, should we consider the new argument as another argument?" and "Can we determine the role and function of such repetition in speech?" must be answered, and researchers should determine the rules and the boundaries for such situations.

In their compilation study on the structures of argument analysis, Sampson and Clark (2008) have studied many structures of argument analysis in literature. As a result of the review, they have identified two difficulties regarding the Toulmin model. First, some of the expressions correspond to more than one argument component at the same time, and secondly, when the arguments are long, expressions can lead to contradictions about analysis as they can be thought as a new claim or as a justification for a claim. They have emphasized that a researcher commenting on what is to be counted as a claim, data or justification according to his/her personal point of view would adversely affect the internal reliability of the argument analysis. Researchers who stated that importance is given to whether data, justifications and supporting in Toulmin's analytic structure exist or not instead of whether they are true or not, have suggested that those who want to examine the content of an argument should support the Toulmin argument model with other measurements. Additionally, due to the fact that Toulmin's argumentation model is suitable for short discussion and that some concepts are not explicitly expressed, it leads to uncertainty in discussion and creates a limited schema (Niaz, Alguilera, Maza, \& Liendo, 2002; Zeidler, 1997).

\subsection{Domain-Specific (Dependent) Models}

Models developed under this heading are used only in the evaluation of the arguments produced in science or in any branch of science. There are four different models that are evaluated in the domain-specific context. Domain-specific models are explained in Table 3. 
Table 3. Domain-specific models

\begin{tabular}{|c|c|}
\hline $\begin{array}{l}\text { Giere } \\
(1991)\end{array}$ & $\begin{array}{l}\text { this model of Giere (1991), scientists generate data after the process of observing and experimenting with the } \\
\text { l-world situations. This process is then entered into the forecasting process by calculation and reasoning. By } \\
\text { mparing the data and the predictions, the competing theories are controlled. In fact, the process that is important for } \\
\text { scientists is to arrive at the most acceptable scientific explanations by determining the theory and the model that best } \\
\text { shat is available. The model used here is essentially aimed at achieving what is most convincing by comparing the } \\
\text { coretical world with the actual world (Aktamış \& Hiğde, 2015; Ceylan, 2012; Driver et al., 2000). }\end{array}$ \\
\hline $\begin{array}{l}\mathrm{Z} \\
\mathrm{M}\end{array}$ & $\begin{array}{l}\text { is model makes it possible to evaluate the quality of written arguments produced by students in the context of 'the } \\
\text { atent of the justification for an argument'. Zohar and Nemet (2002) state that the argument consists both of assertions } \\
\text { conclusions, as well as their justifications, and that they consist of reasons or supporters (Aktamıs \& Hiğde, 2015). } \\
\text { ong arguments in this model have multiple full justifications for supporting the results that combine relevant, } \\
\text { ecific, precise scientific concepts and facts (Erduran, 2008). Weak arguments consist of irrelevant justifications } \\
\text { uschl, 2008). }\end{array}$ \\
\hline & $\begin{array}{l}\text { The most important factor determining the quality of an argument in the model developed by Kelly and Takao (2002) is } \\
\text { the epistemological level that the argument has. In this model, researchers first find the arguments and classify them } \\
\text { according to } 6 \text { epistemic levels (Kelly \& Takao, 2002). These epistemic levels are defined by disciplinary special } \\
\text { structures and reflect a general difference between the lower level definitions of the data and the epistemologically } \\
\text { higher levels that are related to the theories of a particular field (Sampson \& Clark, 2008). After making these } \\
\text { definitions, the researchers define how these propositions are related to each other, and then they use this knowledge to } \\
\text { prepare the diagram that shows the graphical structure of the argument. Through this graphical representation, it is } \\
\text { examined how one associates and coordinates his/her suggestions (Aktamıs \& Hiğde, 2015). }\end{array}$ \\
\hline & $\begin{array}{l}\text { Lawson (2003) focuses on the hypothetical-deductive validity of an argument. Lawson (2003) argues that science } \\
\text { educators need to help students understand how arguments are created and how they are evaluated by scientists, instead } \\
\text { of solely explaining the arguments in general terms. In this model, argumentation begins with a perplexing observation, } \\
\text { which leads to a number of explanations that may change and cause a question. It must then be tested in order to ensure } \\
\text { the validity of the statements and the statement to be subjected to this test is deemed to be correct first. Tests are } \\
\text { designed to obtain observable results. Words such as "if," and "after" are used to associate the test designed to make } \\
\text { predictions with explanations. When this planned test is applied, multiple observable results are obtained and they } \\
\text { constitute evidence. The evidence is compared with the prediction, and the validity of the disclosure is determined as a } \\
\text { result of the predicted verification or the disapproval of the evidence (Aktamış \& Hiğde, 2015; Sampson \& Clark, } \\
2008 \text { ). }\end{array}$ \\
\hline $\begin{array}{l}\text { Sandoval Model } \\
(2003)\end{array}$ & $\begin{array}{l}\text { ndoval (2003) presented a model considering that scientific approaches and approaches based on the evaluation of } \\
\text { se arguments should not be deprived of epistemological and conceptual qualities (Aktamış \& Hiğde, 2015; Sampson } \\
\text { Clark, 2008). This model is a discipline and domain-specific model. Sandoval measures the quality of the arguments } \\
\text { how well students explain their causal claims in a domain-specific theoretical framework, and how well-justified } \\
\text { se claims are by using existing evidence (Sandoval \& Millwood, 2005). The students' justification of a claim is } \\
\text { termined with as much data as possible, the coherent causal explanation for an event, and the combination of } \\
\text { oropriate rhetorical references while giving a reference to a verse defining the epistemological quality of the } \\
\text { suments (Aktamıs \& Hiğde, 2015; Sandoval, 2003; Sandoval \& Millwood, 2005). }\end{array}$ \\
\hline $\begin{array}{l}\text { McNeill, Lizotte, } \\
\text { Krajcik and Marx } \\
\text { Model (2006) }\end{array}$ & $\begin{array}{l}\text { In this model, scientific argumentation is evaluated in three components as claim, evidence and reasoning. Claim is a } \\
\text { statement or a conclusion sentence which students try to answer or that answers the original problem. This component is } \\
\text { the easiest component for students. Evidence is the scientific evidence supporting the claim. Evidence can also come } \\
\text { from studies completed by students or from secondhand sources such as newspapers, books or the internet. The } \\
\text { evidence should be adequate and appropriate. It is meant to be relevant to the current question and to help students } \\
\text { express their direct claims (McNeill et al., 2006; McNeill \& Martin, 2011). Adequacy means that students consider and } \\
\text { use multiple pieces of evidence to support the claim rather than relying on a single piece of data (McNeill et al., 2006). } \\
\text { Reasoning is justification of why data is accepted as evidence in order to support the claim which needs the use of } \\
\text { scientific principles (McNeill et al., 2006; McNeill \& Martin, 2011; Sampson \& Clark, 2008). }\end{array}$ \\
\hline
\end{tabular}

\section{Student's Role in Argumentation}

Researchers are stressing that argumentation should be used as a tool for improving through scientific explanations in science education. Andriessen (2006) characterizes this form of argumentation as "discussing for learning" created by the collaboration of groups studying the same subject. From this point of view, solving a dispute is a way of explaining a scientific phenomenon by the collaboration of individuals which is accomplished by working to determine the explanations that give the best evidences and comparing supporting explanations with 
disagreements (Berland, 2008). From this point of view, argumentation improves the reasoning skills of students and enables them to reveal their ideas. When students believe in the benefits of their discussions, the discussions they make will be of higher quality, and their personal and social development will be positively affected. As Erduran and her colleagues (2006) expressed, responsibility belongs to the student in argumentation. It is the student who makes the claim. Also, they stressed that making students think about the link between the argument that they create during the argumentation process and the evidence put forth as a support for that argument would improve their critical thinking skills. Argumentation is seen as an effective approach that can be used in science education for students to work collaboratively in the problem-solving process, to learn their responsibilities, to be able to think the way scientists do and to understand the nature of science (Eichinger et al., 1991).

\section{Teacher's Role in Argumentation}

It is also the duty of the teacher to apply the argumentation activities in the specified manner. Teachers have a very significant role in practicing argumentation in classrooms. If argumentation activities are to be carried out in a class, the class must first be prepared for discussion. The teacher has an important position in providing students with reliable environments where they can express their ideas and opinions comfortably, to encourage the class to work in collaboration and to make students support the arguments they create with claims, backings and justifications (Jiménez-Aleixandre et al., 2000). At the same time, with the argumentation practices, the teacher helps the students to develop such higher cognitive skills as analysis, synthesis and evaluation (Duschl \& Osborne, 2002). Throughout the argumentation process, the teacher should support students with writing activities as well as oral activities and should be able to give them instructions (Driver, Asoko, Leach, Scott, \& Mortimer, 1994; Duschl \& Osborne, 2002; Kuhn, Shaw, \& Felton, 1997).

\section{Activities that Create an Argumentation Environment}

The activities used to create an argumentation environment in science classes are as follows (Osborne, Erduran, \& Simon, 2004b):

\subsection{Expressions Table}

In this activity, a table that carries expressions of a certain science course subject is given to students. Students are then asked to tell if they agree or not on the given expressions and to discuss the expressions that they choose.

\subsection{Concept Map of Students' Ideas}

Based on the research done in literature, a concept map about science that includes expressions is given to students. Students are then asked to discuss the concepts on the map and on the links between concepts and to make decisions about whether they are scientifically right or wrong, and to suggest reasons and arguments for their decisions both individually and in groups.

\subsection{Experiment Report Prepared by Students}

Students are given another student's experiment report and results. The experiment report includes misconceptions or deficiencies. Thus, students are directed to object. They are asked to express their thoughts about the experiment and how in their opinions the results of the experiment could be fixed.

\subsection{Theories Competing in the Form of Concept Cartoons}

Students are presented with two or more competing theories in the form of cartoons. They are asked to express the theory they believe and to discuss why they think the theory that they choose is true.

\subsection{Theories Competing in the Form of a Story}

Competing theories are given to students in the form of a story. Students are asked to tell which theory they believe is true and to put forth evidences for why they believe that theory.

\subsection{Theories Competing with Ideas and Evidences}

In this activity, a physical phenomenon is introduced to the students and then two or more competing explanations are given about that phenomenon. Additionally, students are provided with a series of evidences that are supporting one, the other, both or neither of these explanations. After that, the students are asked to form small groups and to think about evidence in order to find and evaluate the role and importance of the evidence. Therefore, with this activity, the students have to use evidence when discussing the ideas.

\subsection{Structuring an Argument}

Students are given the explanation of a physical phenomenon and many data expressions about this situation. Then they are asked to discuss which data expression gives the most powerful explanation for this phenomenon by 
structuring an argument on why it gives the most powerful explanation.

\subsection{Predict-Observe-Explain}

In this activity, a phenomenon is introduced without showing and students are asked to discuss what will happen when the phenomenon is started and to justify their reasons. After that, the phenomenon is shown to them. If the result occurs to be different from what is expected, students are asked to rethink and re-evaluate their arguments in the beginning.

\subsection{An Experiment Design}

Students are asked to work in pairs to design an experiment in order to test a hypothesis. Then pairs come together to discuss their designs, suggesting alternative procedures and to discuss their relative evaluations.

\section{Difficulties with the Implementation of the Argumentation in the Learning Environment}

Advantages of argumentation, which is the process of reaching the most accurate knowledge among different arguments, cannot be ignored. However, the approach of learning with argumentation and the cultural background that comes with this approach are not completely flawless (Krajcik et al., 1998). Studies on the subject of argumentation clarify various difficulties faced by students during the process such as students' inability to behave naturally and simply. For example, not sharing the epistemological goals of the implementation that is being done and not fully understanding what they are doing are shown as reasons for students' not entering the argumentation process. Although research on argumentation in science education has continued intensely over the past years, it is thought that such problems in the performances of students occur due to the short periods of education time such as a couple of days or weeks (Gümrah, 2013).

Studies indicate that argumentation learning covers certain cognitive skills. This could be improved through practice, but it is usually hard to learn. Some possible cognitive problems during argumentation can be mentioned: not being able to form cause-result relations, not being able to give meaning to phenomenon leveled knowledge in context, not being able to show evidences, not being able to determine shifts in themes, not being able to identify the elements related to the discussion, not being able to create alternative thoughts and common epistemic views (Hogan, 2000; Jiménez et al., 2000; Kuhn, 1991).

Traditional science education, which is widely adopted in schools, is causing difficulties as a positivist science understanding that includes clear truths and unquestionably accepted results are reached from data. Because of this apprehension, students generally tend to see science as a whole absolute truth about the world instead of a process of creating theories/models and testing them (Driver et., 1994). In connection with this, students' tendency to not understand how scientific knowledge is structured and limited, their tendency to not think that the same data can be interpreted in different ways, and their tendency to not understand that the knowledge put forth are not real discovered facts but claims that need to be supported by justifications are some important problems that can make it difficult to implement argumentation.

Faults and false attitudes present in the argument construction process are also problems in argumentation. Some problems related to attitudes towards argumentation are verbal rudeness, not listening to others, withdrawal from discussion, trying to impose views to another group without considering relativeness of those views to the subject and insisting on a piece of knowledge that has the possibility of being incorrect (Infante, 1987; Infante et al., 1984).

Ryu and Sandoval (2012) listed some of the hardships faced by students when structuring an argument:

- Students are challenged to procure data that is suitable for their arguments.

- They are not able to request data from each other.

- Similarly, students are not successful in rebutting an argument and presenting a counterargument when needed.

- Rebuttals are usually ignored. Although arguments progress in a way that mutual claims are spoken of, no effort is being made by students in order to truly contribute to the competing arguments or stating the supports for their arguments.

- When students procure data, they are challenged to make the connection between the data and their argument. In other words, they are challenged to justify their arguments. This appears to be the hardest part of developing argumentation throughout learning (Clark \& Sampson, 2008; Erduran et al., 2004; Jiménez-Aleixandre et al., 2000; Sandoval, 2003; Sandoval \& Millwood, 2005).

\section{Scientific Argumentation}

Scientific argumentation can be defined as a social activity in which the persuasion process is experienced through 
justification of ideas to explain different points of view and thoughts with a positive critical perspective to overcome the mutual "ambiguity" arising from different points of view and arguments submitted about a subject; to try and uncover the facts and the unknowns in a complete way, and while doing that using not only language but also visuals and texts to produce a solution to problems (Driver et al., 2000; Simon, Erduran, \& Osborne, 2006). In other words, scientific argumentation can be explained as a process containing social and mental activities in which individuals exchange ideas among themselves, and by presenting written scientific facts or via conversing about those facts, and trying to persuade each other about their ideas being correct and factual (Hakyolu, 2010; Kitcher, 1998).

Scientific argumentation is not an evaluation of the individual. On the contrary, it is a communication process that can be conducted individually or in groups to change the opinions of the individuals in order to eliminate different points of view (Van Eemeren \& Grootendorst, 2004). The concept of scientific argumentation should not be confused with the concept of debate. While debates are arguments with both a losing side and a winning side, scientific argumentation is defined as a process of sharing ideas by using scientific evidences between the individuals (Driver et al., 2000; Kuhn, 1993). Scientific argumentation does not have competitive individuals; it has individuals who exchange ideas with available data and by putting forward evidences (Hakyolu, 2010). Scientific argumentation takes place in an environment where arguments are being created. For that reason, realistic arguments are needed in order to convince the individuals and to increase the semantic level of the discussion (Yeşiloğlu, 2007). While arguments are statements made in the light of claims, data, reasons and backings; scientific argumentation is a process in which these are combined and conversed (Simon, Erduran, \& Osborne, 2006). On the other hand, scientific argumentation is a community idea where there are no direct answers to questions between a teacher and students, with students in the center of it, sharing the rich and acceptable criteria of knowledge (Deveci, 2009). At the heart of scientific argumentation lies the idea of in-group or individual interactions based on persuading the other by presenting valid and acceptable alternative ideas (Clark \& Sampson, 2008).

Van Eemeren et al., (1996) express the characteristic aspects of the scientific argumentation as follows:

- An activity of judging in which the speaker explains her/his ideas on a certain subject.

- An oral activity which is executed with a simple language.

- A social activity conducted with other individuals.

- It is always about a specific idea on a certain subject. Scientific argumentation is needed when an opposing idea is present, or considered to be present.

- The goal is to increase the acceptability of an important point for the speaker or the audience.

Scientific argumentation is generally an oral and social reasoning activity. A person in this process asks questions, specifies conditions, opposes ideas, and answers questions while using a certain vocabulary for all those actions. Presenting an idea is not enough on its own, arguments must be open to other points of view too. Consequently, the point of scientific argumentation is to verify or to refute an idea (Van Eemeren et al., 1996).

Studies show that scientific argumentation may have an important impact on literacy if it is integrated into education (Driver et al., 2000; Duschl \& Osborne, 2002). Erduran (2008) points out in a broader way that scientific argumentation is an important goal for science education. It is one of the focuses of science education to have the students active in field-specific events. Also, in arguments held in order to acquire scientific knowledge, the usage of evidence and the validity of the evidence depends on the evaluation of the claimed idea (Kaya \& K1liç, 2008). Ford (2008) points out that scientific argumentation helps students in building knowledge. If the students do not question the knowledge they gain in their cultural environment in debates, they will be obligated to accept the ideas of another individual who can defend their ideas reasonably and strongly. Therefore, scientific argumentation has an important role in scientific education to configure scientific knowledge. Cross, Taasoobshirazi, Hendricks, and Hickey (2008) explain that when students are learning scientific terms, it is necessary for them to interact with their peers and the best way to achieve that is through argumentation. Berland and Reiser (2009) tell that scientific argumentation is a questioning practice which is gaining importance for the science students.

\subsection{The Role of Scientific Argumentation in Science Education}

A great lot of research has been done by researchers in order to find out which educational technique is more efficient and what environmental conditions and what circumstances are needed for science courses to be more effective and fruitful for students (Khine, 2012; Kuhn, 1993b; Osborne, Erduran, \& Simon, 2004a; Zohar \& Nemet, 2002). As a result of such research, it has been observed that teaching methods and techniques for science teaching have been revised in the social context in the recent years (Kuhn, 1992; Osborne, Erduran, \& Simon, 
2004a). By re-interpreting science teaching from a social constructivist perspective, it is now understood that science is not only an experimental activity that uses scientific processes, but also a social activity that includes debates, rejections and objections, and questions the nature of scientific knowledge by talking and debating (Erduran \& Jiménez-Aleixandre, 2007). In this context, argumentation in science teaching is a very significant method since it broadens visions of the students, enables them to understand the nature of science and to configure and develop the concepts of science (Herrenkohl \& Guerra, 1999). The main aim of argumentation in the context of science teaching consists of improving the abilities of students to support their claims by using evidences (Hodson, 2003; Kelly, Regev, \& Prothero, 2008; Sandoval \& Millwood, 2008; Yore et al., 2006). In other words, during the process of science education, using activities based on argumentation would enable the students to produce scientific knowledge since students would defend their claims by using the evidences and the data they obtained during the process (Duschl \& Ellenbogen, 1999).

Researchers have made clear that for young students who are learning science, an active participation in both writing and talking processes is necessary in order to make them think about scientific cases, experiments and explanations that are given to them (Driver et al. 1994; Simon \& Johnson, 2008). According to the principles of constructivist approach, argumentation activities are the primary activity during these writing and talking processes (Driver et al., 2000; Newton, Driver, \& Osborne, 1999) because students can clearly express the causes that are supporting their views and strive to prove them by making use of their preliminary knowledge thanks to the argumentation technique. Other students also express their opposite views clearly, explain their doubts and present alternative ideas. Therefore, students work like scientists; they come up with support and reason in order to prove their claims (Driver et al., 1994; Newton et al., 1999; Siegel, 1995). Students who think deeply on the arguments and counter arguments activate their metacognitive skills and this creates a conceptual change (Dole \& Sinatra, 1998). Therefore, in that context, it can be said that argumentation enables the individuals to see and evaluate each perspective at the same time and makes them see different perspectives and create deeper knowledge (Yeh \& She, 2010). Thus, students can realize how they get to know a piece of knowledge and consolidate their scientific knowledge. Additionally, on the one hand, students are being directed to think the way scientists do and they are made to learn permanently, and on the other hand, their quality of living is much better.

In science literature, it has been frequently emphasized in many studies that one of the main aims of argumentation practices for students is to increase their ability to think critically (Erduran et al., 2006; Kuhn, 1993; Simon, Erduran, \& Osborne, 2006), make them understand how scientific mechanisms work and how scientific studies are materialized (Driver et al., 2000; Duschl, 2008). It also makes them good citizens (Kolstø, 2001). These qualities point out to the attributes that are needed to be gained by students in order to make them democratic participants. However, for students to be well informed participants in democratic societies, improving the use of argumentation abilities is shown as a necessity (American Association for the Advancement of Science [AAAS], 1990, 1993; Organisation for Economic Cooperation and Development [OECD], 1998).

Making students have a better understanding of scientists and making them see what scientific processes are used by scientists in order to get scientific knowledge is seen as an essential component of science literacy. One way of developing science literacy is making students develop abilities of meaningful and effective understanding of science course subjects. Argumentation is at the center of methods that help students in the development of science literacy based on scientific reasoning skills (AAAS, 1993; National Research Council [NRC], 2000). Explanations given during the process of argumentation enables students to realize what the data mean and what conclusions can be reached by students from the data, and the data are provided for students to criticize, argue and revise (Driver et al., 2000; Sandoval \& Reiser, 2004). Thus, participating in an efficient argumentation and effectively actualizing this process is evaluated as an indicator of science literacy (Driver et al., 1994; Driver et al., 2000; Erduran et al., 2004; Jiménez-Aleixandre et al., 2000, Kuhn, 1993).

From a cognitive point of view, argumentation in science education includes the individuals' ability of reasoning. Expressing ideas in the classroom makes the student steer from inner psychological area (mind) to outer psychological area (classroom). Students, as a result of their agreement on the benefits of a discussion, improve both themselves and their friends by making quality discussions. The interaction of students in personal and social areas enables them to develop their common knowledge, values and beliefs (Erduran et al., 2006; Simon, Erduran, \& Osborne, 2006). Also, significant abilities of problem solving and decision making can be developed by making such discussions on scientific issues in daily life or social problems (Kuhn, 1993).

One other reason for promoting argumentation in science education with special emphasis is the potential it has for assisting students in understanding the epistemic views of science in argumentation (Driver et al., 2000; Duschl, 2008; Kuhn, 1993). For example, Duschl (2008) argues that making argumentation forms a bridge between science education from epistemic and conceptual aspects and creating scientific meanings from social 
aspects. Although argumentation helps the epistemic views of science to be understood, it has been studied by a very few numbers of researchers (McDonald \& McRobbie, 2012).

According to Erduran and Jiménez-Aleixandre (2007), argumentation method used in science education is helpful in the sense that it;

a) Enables the pre-knowledge to appear and teachers to evaluate what students understand,

b) Helps students to create scientific arguments and logical deductions by using the methods such as big group discussions,

c) Enables students to talk about their ideas, to get involved in groups and to base their thoughts on scientific facts,

d) Enables students to feel the differences and similarities between their thoughts and the thoughts of others (including scientists),

e) Supports scientific thinking,

f) Increases motivation of students who now see similar claims made by their peers (Erduran \& Jiménez-Aleixandre, 2007).

\subsection{Scientific Argumentation and Epistemological Orientations}

Argumentation at the same time is a discursive activity, so it has a special significance in terms of reflecting the judgments that individuals have. It has been observed that because of this quality of argumentation, it is being used as both a written (Kelly \& Takao, 2002) and spoken (Jiménez-Aleixandre, Rodriguez, \& Duschl, 2000; Kuhn, 1993) tool for revealing the epistemological features of individuals. During argumentation, it has been observed that most individuals get involved in the process according to their epistemological beliefs when they are given data and evidences about an event (Kuhn, 1993). This is also parallel with Posner et al.'s (1982) conceptual change model. According to Posner and friends, one side of the individuals' conceptual ecology is the epistemological features and metaphysical beliefs. For an individual to adopt a new concept, the individual must be reasonable and causative. In this context, it has been put forth that there are similarities between an individual's structure of belief and cognitive structure.

\section{References}

Aktamış, H., \& Hiğde, E. (2015). Fen eğitiminde kullanılan argümantasyon modellerinin değerlendirilmesi. Mehmet Akif Ersoy Üniversitesi Ĕ̌itim Fakültesi Dergisi, 1(35), 136-172.

Aldağ, H. (2005). Düşünme aracı olarak metinsel ve metinsel grafiksel tartışma yazılımının tartışma becerilerinin geliştirilmesine etkisi (Unpublished doctoral dissertation). Çukurova University, Adana.

American Association for the Advancement of Science [AAAS]. (1990). Science for all Americans. New York: Oxford University Press.

American Association for the Advancement of Science [AAAS]. (1993). Benchmarks for science literacy. Oxford, UK: Oxford University Press.

Andriessen, J. (2006). Arguing to learn. In K. Sawyer (Ed.), The Cambridge handbook of the learning sciences (pp. 443-459). Cambridge: Cambridge University Press. https://doi.org/10.1017/CBO9780511816833.027

Berland, L. K. (2008). Understanding the composite practice that forms when classrooms take up the practice of scientific argumentation (Unpublished doctoral dissertation). Northwestern University, Evanston.

Berland, L. K., \& Reiser, B. J. (2009). Making sense of argumentation and explanation. Science Education, 93(1), 26-55. https://doi.org/10.1002/sce.20286

Binkley, R. W. (1995). Argumentation, education and reasoning. Informal Logic, 17(2), $127-143$. https://doi.org/10.22329/il.v17i2.2403

Bricker, L., \& Bell, P. (2008). Conceptualizations of argumentation from science studies and the learning sciences and their implications for the practices of science education. Science Education, 92, 473-498. https://doi.org/10.1002/sce.20278

Ceylan, K. E. (2012). Illköğretim 5. sınıf öğrencilerine dünya ve evren öğrenme alanının bilimsel tartışma (argümantasyon) odakl yöntem ile ögretimi (Unpublished master thesis). Gazi University, Ankara.

Clark, D. B., \& Sampson, V. (2008). Assessing dialogic argumentation in online environments to relate structure, grounds, and conceptual quality. Journal of Research in Science Teaching, 45(3), $293-321$. https://doi.org/10.1002/tea.20216 
Cross, D., Taasoobshirazi, G., Hendricks, S., \& Hickey, D. T. (2008). Argumentation: A strategy for improving achievement and revealing scientific identities. International Journal of Science Education, 30(6), 837-861. https://doi.org/10.1080/09500690701411567

Deveci, A. (2009). İlköğretim yedinci sını öğrencilerinin maddenin yapısı konusunda sosyobilimsel argümantasyon, bilgi seviyeleri ve bilişsel düşünme becerilerini geliştirmek (Unpublished master thesis). Marmara University, İstanbul.

Dole, J. A., \& Sinatra, G. M. (1998). Reconceptalizing change in the cognitive construction of knowledge. Educational Psychologist, 33(2-3), 109-128. https://doi.org/10.1080/00461520.1998.9653294

Driver, R., Asoko, H., Leach, J., Scott, P., \& Mortimer, E. (1994). Constructing scientific knowledge in the classroom. Educational Researcher, 23(7), 5-12. https://doi.org/10.3102/0013189X023007005

Driver, R., Newton, P., \& Osborne, J. (2000). Establishing the norms of scientific argumentation in classrooms. $\begin{array}{lll}\text { Science } & \text { Education, 84(3), 287-312. }\end{array}$ https://doi.org/10.1002/(SICI)1098-237X(200005)84:3<287::AID-SCE1>3.0.CO;2-A

Duschl, R. A. (2008). Science education in three-part harmony: Balancing conceptual, epistemic, and social learning goals. Review of Research in Education, 32(1), 268-291. https://doi.org/10.3102/0091732X07309371

Duschl, R. A., \& Osborne, J. (2002). Supporting and promoting argumentation discourse. Studies in Science Education, 38, 39-72. https://doi.org/10.1080/03057260208560187

Duschl, R. A., Ellenbogen, K., \& Erduran, S. (1999). Middle school students' dialogic argumentation. In M. Komorek, H. Behrendt, H. Dahncke, R. Duit, W. Gräber, \& A. Kross (Eds.), Research in science education: Past, present and future; Proceedings of the Second International Conference of the European Science Education Research Association (pp. 420-422). Kiel: IPN.

Eichinger, D. C., Anderson, C. W., Palinscar, A., \& David, Y. M. (1991). An illustration of the roles of content knowledge, scientific argument, and social norms in collaborative problem solving. Paper presented at the American Educational Research Association (AERA) Annual Meeting, Chicago, IL.

Erduran, S. (2008). Methodological Foundations in the Study of Argumentation in Science Classrooms. In S. Erduran, \& M. P. Jiménez-Aleixandre (Eds.), Argumentation in Science Education (pp. 47-69). UK: Springer Science \& Business Media. https://doi.org/10.1007/978-1-4020-6670-2_3

Erduran, S., \& Jiménez-Aleixandre, M. P. (Eds.). (2007). Argumentation in Science Education. Berlin: Springer. https://doi.org/10.1007/978-1-4020-6670-2

Erduran, S., Ardac, D., \& Yakmaci-Guzel, B. (2006). Learning to teach argumentation: Case studies of pre-service secondary science teachers. Eurasia Journal of Mathematics, Science and Technology Education, 2(2), 1-14. https://doi.org/10.12973/ejmste/75442

Erduran, S., Simon, S., \& Osborne, J. (2004). TAPping into argumentation: Developments in the application of Toulmin's argument pattern for studying science discourse. Science Education, 88(6), 915-933. https://doi.org/10.1002/sce. 20012

Ford, M. (2008). Disciplinary authority and accountability in scientific practice and learning. Science Education, 92(3), 404-423. https://doi.org/10.1002/sce.20263

Giere, R.N. (1991). Understanding scientific reasoning (3rd ed.). Fort Worth, TX: Holt, Reinhart \& Winston.

Greenwell, W., Knight, J. C., Holloway, C. M., \& Pease, J. J. (2005). A taxonomy of fallacies in system safety arguments. Paper presented at the 24th International System Safety Conference, Albuquerque, New Mexico.

Gümrah, A. (2013). Bilimsel tartışma yönteminin ortä̈ğretim öğrencilerinin kimyasal değişim konusunu anlamaları, bilimin doğası hakkındaki görüşleri, bilimsel süreç, iletişsim ve argüman becerileri üzerine etkisi (Unpublished doctoral dissertation). Marmara University, İstanbul.

Hakyolu, H. (2010). Farkl öğrenme seviyelerindeki öğrencilerin fen derslerinde oluşturulan argüman ortamlarındaki performansları (Unpublished master thesis). Marmara University, İstanbul.

Herrenkohl, L. R., \& Guerra, M. R. (1999). Moving classrooms beyond transmission models of teaching and learning: A teacher-researcher collaborative model. In R. Bibace, J. J. Dillon, \& B. N. Dowds (Eds.), Partnerships in research, clinical and educational settings (pp. 161-178). Stamford, CT: Ablex.

Hodson, D. (2003). Time for action: Science education for an alternative future. International Journal of Science 
Education, 25(6), 645-670. https://doi.org/10.1080/09500690305021

Hogan, K. (2000). Exploring a process view of students' knowledge about the nature of science. Science Education, $84(1)$,

$51-70$.

https://doi.org/10.1002/(SICI)1098-237X(200001)84:1<51::AID-SCE5>3.0.CO;2-H

Infante, D. A. (1987). Aggressiveness. In J. C. McCroskey, \& J. A. Daly (Eds.), Personality and interpersonal communication (pp. 157-192). Newbury Park, CA: Sage.

Infante, D. A., Trebing, J. D., Shepherd, P. E., \& Seeds, D. E. (1984). The relationship of argumentativeness to $\begin{array}{lllll}\text { verbal aggression. Southern Speech Communication Journal, } & \text { 50(1), }\end{array}$ https://doi.org/10.1080/10417948409372622

Jiménez-Aleixandre, M. P., Rodriguez, A. B., \& Duschl, R. A. (2000). "Doing the lesson" or" doing science": Argument in high school genetics. Science Education, 84(6), 757-792. https://doi.org/10.1002/1098-237X(200011)84:6<757::AID-SCE5>3.0.CO;2-F

Johnson, R., \& Blair, J. (1994). Informal Logic: Past and Present. In R. H. Johnson, \& J. A. Blair (Eds.), New Essays in Informal Logic. Windsor, ON: Informal Logic.

Kaya, O. N., \& Kılıç, Z. (2008). Argumentative discourse for effective science teaching. Kırşehir Journal of Education Faculty, 9(3), 89-100.

Kelly, G. J., \& Takao, A. (2002). Epistemic levels in argument: An analysis of university oceanography students' use of evidence in writing. Science Education, 86(3), 314-342. https://doi.org/10.1002/sce.10024

Kelly, G. J., Regev, J., \& Prothero, W. (2008). Analysis of lines of reasoning in written argumentation. In S. Erduran \& M. P. Jimenez-Aleixandre (Eds.), Argumentation in science education: Perspectives from classroom-based research (pp. 137-158). Netherlands: Springer. https://doi.org/10.1007/978-1-4020-6670-2_7

Khine, M. S. (2012). Perspectives on scientific argumentation: Theory, practice, and research. Dordrecht: Springer. https://doi.org/10.1007/978-94-007-2470-9

Kitcher, P. (1988). The child as parent of the scientist. Minds of Language, 3(3), 215-228. https://doi.org/10.1111/j.1468-0017.1988.tb00144.x

Kolstø, S. D. (2001). To trust or not to trust: pupils' ways of judging information encountered in a socio-scientific issue. International Journal of Science Education, 23(9), 877-901. https://doi.org/10.1080/09500690010016102

Krajcik, J., Blumenfeld, P. C., Marx, R. W., Bass, K. M., Fredricks, J., \& Soloway, E. (1998). Inquiry in project-based science classrooms: Initial attempts by middle school students. Journal of the Learning Sciences, 7(3-4), 313-350. https://doi.org/10.1080/10508406.1998.9672057

Kuhn, D. (1991). The skills of argument. Cambridge: Cambridge University Press. https://doi.org/10.1017/CBO9780511571350

Kuhn, D. (1992). Thinking as argument. Harvard Educational Review, 62(2), 155-179. https://doi.org/10.17763/haer.62.2.9r424r0113t67011

Kuhn, D. (1993). Science as argument: implications for teaching and learning scientific thinking. Science Education, 77, 319-337. https://doi.org/10.1002/sce.3730770306

Kuhn, D. (1993b). Connecting scientific and informal reasoning. Merrill-Palmer Quarterly, 39, 74-103.

Kuhn, D., Shaw, V., \& Felton, M. (1997). Effects of dyadic interaction on argumentive reasoning. Cognition and Instruction, 15, 287-315. https://doi.org/10.1207/s1532690xci1503_1

Kutluca, A. Y. (2012). Fen ve teknoloji ögretmen adaylarının klonlamaya ilişkin bilimsel ve sosyobilimsel argümantasyon kalitelerinin alan bilgisi yönünden incelenmesi (Unpublished master thesis). Abant İzzet Baysal University, Bolu.

Lawson, A. E. (2003). The nature and development of hypothetico-predictive argumentation with implications for science education. International Journal of Science Education, 25(11), 1387-1408. https://doi.org/10.1080/0950069032000052117

Leeman, R. W. (1987). Taking perspectives: Teaching critical thinking in the argumentation course. Paper presented at the Annual Meeting of the Speech Communication Association, Boston, MA. 
Mason, L., \& Santi, M. (1994). Argumentation structure and metacognition in constructing shared knowledge at school. Paper presented at the American Educational Research Association (AERA), Annual Meeting, New Orleans.

McDonald, C. V., \& McRobbie, C. J. (2012). Utilising argumentation to teach nature of science. In B. J. Fraser, K. G. Tobin, \& C. J. McRobbie (Eds.), Second international handbook of science education (Vol. 2, pp. 969-986). Dordrecht, The Netherlands: Springer. https://doi.org/10.1007/978-1-4020-9041-7_64

McNeill, K. L., \& Martin, D. M. (2011). Claims, evidence and reasoning: Demystifying data during a unit on simple machines. Science and Children, 48(8), 52-56.

McNeill, K. L., Lizotte, D. J., Krajcik, J., \& Marx, R. W. (2006). Supporting students' construction of scientific explanations by fading scaffolds in instructional materials. The Journal of the Learning Sciences, 15(2), 153-191. https://doi.org/10.1207/s15327809jls1502_1

National Research Council [NRC]. (2000). Inquiry and the Rational Science Education Standards: A Guide for Teaching and Learning (S. Olson, \& S. Loucks-Horsley, Eds.). Washington, DC: National Academies Press.

Newton, P., Driver, R., \& Osborne, J. (1999). The place of argumentation in the pedagogy of school science. International Journal of Science Education, 21(5), 553-576. https://doi.org/10.1080/095006999290570

Niaz, M., Aguilera, D., Maza, A., \& Liendo, G. (2002). Arguments, contradictions, resistances, and conceptual change in students' understanding of atomic structure. Science Education, 86(4), 505-525. https://doi.org/10.1002/sce.10035

Nussbaum, E. M., \& Bendixen, L. D. (2003). Approaching and avoiding arguments: The role of epistemological beliefs, need for cognition, and extraverted personality traits. Contemporary Educational Psychology, 28(4), 573-595. https://doi.org/10.1016/S0361-476X(02)00062-0

Organisation for Economic Cooperation and Development [OECD]. (1998). Instrument design: A framework for assessing scientific literacy. Report of Project Managers Meeting, Arnhem, The Netherlands: Programme for International Student Assessment.

Osborne, J., Erduran, S., \& Simon, S. (2004a). Enhancing the quality of argument in school science. Journal of Research in Science Teaching, 41(10), 994-1020. https://doi.org/10.1002/tea.20035

Osborne, J., Erduran, S., \& Simon, S. (2004b). Ideas, evidence and argument in science. In-service Training Pack, Resource Pack and Video. London: Nuffield Foundation.

Özkara, D. (2011). Basınç konusunun sekizinci sınıf ögrrencilerine bilimsel argümantasyona dayalı etkinlikler ile ögretilmesi (Unpublished master thesis). Adıyaman University, Adıyaman.

Posner, G. J., Strike, K. A., Hewson, P. W., \& Gertzog, W. A. (1982). Accommodation of a scientific conception: Toward a theory of conceptual change. Science Education, 66(2), 211-227. https://doi.org/10.1002/sce.3730660207

Ryu, S., \& Sandoval, W. A. (2012). Improvements to elementary children's epistemic understanding from sustained argumentation. Science Education, 96(3), 488-526. https://doi.org/10.1002/sce.21006

Sampson, V., \& Clark, D. (2008). Assessment of the ways students generate arguments in science education: Current perspectives and recommendations for future directions. Science Education, 92(3), 447-472. https://doi.org/10.1002/sce.20276

Sandoval, W. A. (2003). The inquiry paradox: why doing inquiry doesn't necessarily mean doing science. Paper presented at the 6th International Conference on Computer-Based Leaning in Science, Nicosia, Cyprus.

Sandoval, W. A., \& Millwood, K. A. (2005). The quality of students' use of evidence in written scientific explanations. Cognition and Instruction, 23(1), 23-55. https://doi.org/10.1207/s1532690xci2301_2

Sandoval, W. A., \& Reiser, B. J. (2004). Explanation-driven inquiry: Integrating conceptual and epistemic scaffolds for scientific inquiry. Science education, 88(3), 345-372. https://doi.org/10.1002/sce.10130

Sandoval, W., \& Millwood, K. (2008). What can argumentation tell us about epistemology? In S. Erduran, \& M. P. Jiménez-Aleixandre (Eds.), Argumentation in science education: Perspectives from classroom-based research (pp. 71-88). New York: Springer. https://doi.org/10.1007/978-1-4020-6670-2_4

Schwarz, B. B., Neuman, Y., Gil, J., \& Ilya, M. (2003). Construction of collective and individual knowledge in argumentative activity. The Journal of the Learning Sciences, 12(2), 219-256. https://doi.org/10.1207/S15327809JLS1202_3 
Siegel, H. (1995). Why should educators care about argumentation? Informal Logic, 17(2), 159-176. https://doi.org/10.22329/il.v17i2.2405

Simon, S., \& Johnson, S. (2008). Professional learning portfolios for argumentation in school science. International Journal of Science Education, 30(5), 669-688. https://doi.org/10.1080/09500690701854873

Simon, S., Erduran, S., \& Osborne, J. (2006). Learning to teach argumentation: Research and development in the science classroom. International Journal of Science Education, 28(2-3), 235-260. https://doi.org/10.1080/09500690500336957

Toulmin, S. E. (1958). The uses of argument. Cambridge: Cambridge University Press.

Toulmin, S. E. (1990). The uses of argument (10th ed.). Cambridge: Cambridge University Press.

Van Eemeren, F. H., \& Grootendorst, R. (2004). A systematic theory of argumentation: The pragma-dialectical approach. Cambridge: Cambridge University Press. https://doi.org/10.1017/CBO9780511616389

Van Eemeren, F. H., Grootendorst, R., Henkemans, F. S., Blair, J. A., Johnson, R. H., Krabbe, E. C., \& Zarefsky, D. (1996). Fundamentals of argumentation theory: A handbook of historical backgrounds and contemporary developments (pp. 163-188). Mahwah, NJ: Lawrence Erlbaum Associates.

Walton, D. (1996). Argumentation schemes for presumptive reasoning. Mahwah, NJ: Erlbaum Press.

Yeh, K. H., \& She, H. C. (2010). On-line synchronous scientific argumentation learning: Nurturing students' argumentation ability and conceptual change in science context. Computers \& Education, 55(2), 586-602. https://doi.org/10.1016/j.compedu.2010.02.020

Yeşiloğlu, S. N. (2007). Gazlar konusunun lise ögrrencilerine bilimsel tartı̧̧ma (argümantasyon) odakll yöntemle ögretimi (Unpublished master thesis). Gazi University, Ankara.

Yore, L. D., Florence, M. K., Pearson, T. W., \& Weaver, A. J. (2006). Written discourse in scientific communities: A conversation with two scientists about their views of science, use of language, role of writing in doing science, and compatibility between their epistemic views and language. International Journal of Science Education, 28(2-3), 109-141. https://doi.org/10.1080/09500690500336601

Zeidler, D. L. (1997). The central role of fallacious thinking in science education. Science Education, 81(4), 483-496. https://doi.org/10.1002/(SICI)1098-237X(199707)81:4<483::AID-SCE7>3.0.CO;2-8

Zohar, A., \& Nemet, F. (2002). Fostering students' knowledge and argumentation skills through dilemmas in human genetics. Journal of Research in Science Teaching, 39(1), 35-62. https://doi.org/10.1002/tea.10008

\section{Copyrights}

Copyright for this article is retained by the author(s), with first publication rights granted to the journal.

This is an open-access article distributed under the terms and conditions of the Creative Commons Attribution license (http://creativecommons.org/licenses/by/4.0/). 